\title{
A hazai mozgásszervi rehabilitáció lehetőségei és intézményrendszere*
}

\author{
DR. CSERHÁTI PÉTER
}

DOI: 10.21755/MTO.2016.059.0304.009

\section{Igen Tisztelt Osztályelnök Úr! \\ Tisztelt Kollégák! \\ Hölgyeim és Uraim!}

Nagy megtiszteltetés számomra, hogy az egykori Országos Traumatológiai Intézet (OTRI) és a hazai baleseti, valamint kézsebészet szoros együtt fejlődésének Renner Antal és Fekete Károly professzor urak által történt bemutatása után a hazai rehabilitációs medicina hasonló útjáról én beszélhetek.

Renner professzor úr igen megérintő módon használta a szubjektív megközelítést, én is így kezdem a témámat. Pontosan 20 évig dolgoztam baleseti sebészként a Fiumei úti épületben, és saját érdeklődésem változása is jól modellezi azt az utat, amelyen hazánkban a klinikai területek mellé felzárkózik a komplex bio-szocio-ökológiai restitúció és társadalmi reintegráció erősödő szemlélete.

A megelőző mútősasszisztensi év majd az egyetemi évek alatt végzett ügyeleti munka után 1988-ban indult segédorvosi pályám az akkori OTRI-ban. A Semmelweis Egyetemen folytatott anatómiai tárgyú tudományos diákköri tevékenységből jól következett a Dr. Manninger Jenő és Dr. Kazár György professzorok által vezetett „Combnyak team” kutatócsoportba való bekapcsolódásom. Első, a tárgyban írt közleményem, 1991-ben jelent meg (7). Egy sikeres ifjúsági OTKA pályázat tette lehetővé, hogy felvegyük a kapcsolatot a Lundi Egyetem (Svédország) Ortopédiai Klinikájának professzorával, Karl-Göran Thorngrennel, akinél 1994-ben töltöttünk először hoszszabb tanulmányi időt Fekete Károly professzor úrral együtt. Ennek nyomán vált lehetővé, hogy bekapcsolódjunk a lundi klinika által meghirdetett Multicenter Hip Fracture Study (MHFS) majd az EU támogatással megvalósuló Standardized Audit of Hip Fracture in Europe (SAHFE) programba. Utóbbi keretében 1997-98-ban 10 ország (olasz, spanyol, görög, magyar, német, holland, belga, brit, svéd, finn) baleseti központjaiba egy év során felvett több mint 5000 friss, osteoporotikus csípőtáji (combnyak és tomportáji) törést elszenvedett sérült premorbid státuszát, baleseti és rehabilitációs ellátását valamint négyhónapos gyógyeredményét elemeztük standardizált adatfeldolgozás révén.

Az elsősorban ortopéd-traumatológusok által vezetett vizsgálat fő célja az volt, hogy az elöregedő európai társadalomban népbetegségként jelentkező kihívás kapcsán nagy esetszámra alapozva tudjon az akkor forrongó terápiás kérdésekre választ adni. Ilyen volt a diszlokált combnyaktörés kezelésében a combfej-megtartó osteosynthesis, vagy primeren csípőprotézis beültetés, illetve a tomportáji törésekben az extramedullaris (DHS) és intramedullaris (rövid velőűrszegezés) eljárás primátusának és indikációjának megállapítása.

*A Magyar Tudományos Akadémia Kupolatermében 2015. november 26-án, a „Csont és ízület 2010-2020 évtizede” program keretében „A mozgásszervi károsodások kezelésének hagyományai és új eredményei hazánkban” címmel szervezett osztályrendezvény "Traumatológia és kézsebészet Magyarországon” Szekció, publikálásra átdolgozott elóadása 
A széleskörű felmérés jól mutatta a dél-, illetve észak-európai, egyébként hasonló átlagéletkorú sérült populációk közötti szocio-kulturális különbségeket is. Előbbiek többsége (92,5-96,2\%) otthonából érkezett felvételre és családtagjaival élt együtt $(83,6-94,4 \%)$, míg utóbbiak jó része $(33,1-46,8 \%)$ valamilyen idősellátó intézményből érkezett, vagy otthonában egyedül élt (45,5-63,2\%). Az akadálymentesség hiánya és a társadalmi attitűd (botnál komolyabb segédeszköz használata a rokkantság jelképe), ugyanakkor a család rendelkezésre álló segítsége magyarázta a kültéri aktivitás és ahhoz rollátor használat (guruló kerekesszék) alacsonyabb arányát Dél-Európában az önellátásra kényszerülő, magányos észak-európai idősekkel szemben a sérülés elött $(2,2-4,8 \%$ vs. $12,1-35,2 \%)$.

Jelentősnek mutatkozott a baleseti ellátás, műtét utáni utókezelői gyakorlat is. Dél-Európában gyakorlatilag nem állt e célból rendelkezésre fekvőbeteg egység, a sérültek többségét (89,6-94,6\%) otthonukba bocsátották vissza. Ezzel szemben Észak-Európában a hazabocsátottak aránya alacsony volt (5,1-29,5\%), többségüket rehabilitációs osztályra vagy szociális intézménybe helyezték át. Négy hónappal a sérülés után jóval alacsonyabb volt a sérült csípőben fájdalmat nem érzők aránya Dél-Európában, mint északon (1-16\% vs. 35,7-51\%), ugyanakkor az elhunytak aránya Dél-Európában volt jóval kedvezőbb 4 hónap után (6,9-12,6\% vs. 14,5-21,6 \%), azaz a szakszerű rehabilitáció jó funkcionális eredménnyel társult, az adatok aláhúzták a családi háttér jelentőségét a túlélés mentális hátterében.

A SAHFE vizsgálat már a korai posztoperatív eredmények kapcsán is rámutatott tehát arra, hogy ilyen nagy betegcsoportok aktív osztályos majd rehabilitációs gyógyeredményében a terápiás gyakorlat (töréstípus, mútéti módszer) mellett a pszicho-szociális, kulturális és szervezeti tényezőknek (családstruktúra, akadálymentesség, társadalmi attitűd) fokozott jelentősége van. Kiemelt jelentőségű az idősek esetében is az önálló életvitel lehetőségének preferálása (hospitalizálódás helyett támogatott lakhatás - home care modell sikere Svédországban). Mindennek különös jelentősége van az idősek arányának növekedésére és az ellátás jobb megszervezésére való felkészülésben (családmodell változása, járulékfizetési képesség csökkenése stb.).

A rehabilitáció mintegy „interface”-t képez az aktív klinikai ellátás és a társadalmi reintegráció között, ami azt is jelenti, hogy azok problémái is itt csapódnak le. Keveset foglalkozik a szakirodalom például a multirezisztens kórokozók (MRK) jelentőségével a rehabilitációs ellátás során, holott az aktív, többnyire intenzív osztályokról áthelyezett súlyos sérültek mind nagyobb számban hoznak ilyen flórát magukkal (az OORI esetében 5 év alatt, a 2009. évi 55-ről 229-re nőtt az igazolt behurcolt törzsek jelenléte 2014-re). Az ÁNTSZ által előírt elkülönítésben ugyanakkor érdemi rehabilitációt végezni nem lehet, a beteg nem tudja igénybe venni a speciális szolgáltatásokat (sport-, hidro-, ergoterápia), az izolációs eszközök, az ismételt antibiotikum kezelések és felszabadító bakteriológiai vizsgálat sorozatok költségei a több hónapos bennfekvés során, valamint a kórteremben lezárt többi ágyon kiesett napidíj bevétel extrém veszteségeket jelent az ellátó intézménynek.

A rehabilitációs ellátásban az OEP által szerződött ágyak száma (15046) közelíti az aktív ágyak számának harmadát, és e volumenen belül jelentős a felnőtt és gyermek pszichiátriai, illetve addiktológiai rehabilitációs ágyak száma (4856). Érdekes adat, hogy a rehabilitációs tevékenység keretében szerződött országos járóbeteg szakorvosi óraszám csak 5,5\%-a a teljes lekötött menynyiségnek, míg a nem szakorvosi órák 77\%-a kötődik a rehabilitációhoz (fizioterápia, logopédia, szakpszichológia stb.). Ez is mutatja a rehabilitációs team tagok munkájának jelentőségét.

A rehabilitációs osztályok sokáig infrastruktúra szempontjából is hátrányos helyzetben voltak az intézményeken belül. Általában utólag, korábbi pavilonok kiürítésével alakították ki őket, és kevés forrást tudtak biztosítani a felújításukra. Ebben a 2007-13 uniós ciklus pályázati lehetőségei hoztak a vidéki konvergencia régiókban jelentős változást. A Regionális Operatív Programok (ROP) keretében ismételt forrásemeléssel közel 19 Mrd Ft-ból 63 intézményben 66 telephelyen újultak meg az épületek, illetve az eszközök. Az egyes térségekben a centrumok (Pécs, Szeged, Debrecen, Miskolc, Győr) által vezetett konzorciumok sikeresen, határidőre befejezték a beruházásokat, amelyekben a 2007. évtől különösen elhanyagolt pszichiátriai és addiktológiai rehabilitációs osztályok, egységek felújítása képezte a prioritást (29,3, illetve 13,6\%-a a teljes keretnek). 
A betegutak problémáira utal ugyanakkor, hogy még 2014-ben is csak a 16\%-a került közvetlenül primer rehabilitációra a népegészségügyi szempontból jelentős csoportoknak (AMI, stroke, csípőtáji töröttek, amputáltak stb.), ahogy azt az IME 2014. június 18-án tartott kongresszusán az OEP adatok alapján demonstrálták. Az adatok tisztítása (elhunytak és enyhe esetek kizárása, kódolási problémák, stb.) után is több ok vethető fel ennek hátterében. A 2010 óta stagnáló bázisfinanszírozás (5600Ft krónikus napidíj) a növekedő költségekkel szemben a rehabilitációs osztályok esetében is felvetheti a „vattabeteg ellátás” kényszerét (a súlyos, nagy költségű esetek kerülését).

A súlyos sérültek rehabilitációja kapcsán számos olyan funkcionális és patológiai helyzettel kell szembenézni, amelyek az aktív ellátás során nem kerülnek előtérbe. Ilyenek a különböző, elsősorban a gerincvelő sérülése után előforduló vaszkuláris reflex problémák (a bénult és az ép testfél eltérő reakcióiból származó autonóm disreflexia, felüléskor ortosztatikus hypotonia, vagy a hőszabályozás károsodása miatti poikilotermia. Az érzészavar a szakrális területek korai és kiterjedt felfekvései miatt akár a mély ízületekbe is betörő szeptikus állapotot képes okozni. Kezelésében legfontosabb a prevenció, a fekve forgatás, a kerekes székes életmód részeként a rendszeres kiemelkedés megtanítása, a higiéné utáni test ellenőrzés tükör segítségével, a speciális lábbelik, légkamrák, decubitus párnák és matracok használata.

A konzervatív kezelésre nem gyógyuló decubitusok plasztikai sebészeti kezelése az utóbbi években kezdődött meg hazánkban, ezeket elsősorban az OORI-ban végzik. Ennek része az onkológiai radikalitással végzett kimetszés és fedés elforgatott gluteus maximus, tractus iliotibialis, illetve biceps femoris kompozit lebenyekkel (sacralis, trochantericus, illetve tuber ischii feletti elhelyezkedésnél), majd azt követő hat hét hason fekvés vagy homokágy tehermentesítés.

Az egyre jobban fejlődő „rehabilitációs sebészet” tárgykörébe sorolhatók azok az eljárások is, amelyek révén például lehetséges az alsóvégtagi automácia részeként kialakult, az életminőséget súlyosan befolyásoló spaszticitás csökkentése, a gerincvelőbe folyamatos baclofen adagolást végző pumpa beültetésével (neuromoduláció). Az ilyen gerincvelő sérültek gondozását az OORI megfelelő osztálya végzi. Szintén a rehabilitációs folyamat során jelentkezik az azt súlyosan akadályozó, az agy- vagy gerincvelősérülést gyakran kísérő csípő- vagy térdízületi heterotop ossificatio, amelynek a kivizsgálása (3D CT), mútéti tervezése és eltávolítása komplex ismereteket és gyakorlatot kíván.

Hasonlóan új eljárás a súlyos sérülésekkel összefüggő légúti szövődmények, a bordaközti izmok vagy a rekesz bénulás ellátásában a beteg életminőségét súlyosan rontó noninvazív ventilláció (NIV), illetve otthoni gépi lélegeztető készülék használata helyett rekesz pacemaker beültetése, amiből az elsőt hazánkban is elvégezték, az utógondozás az OORI-ban történt.

A legtöbb problémát okozó hólyag ürítési zavarok kezelésében az intermittáló katéterezés megtanulását és elvégzését egyre könnyebbé teszi a húgycső falát nem sértő hidrofil bevonatú eszközök, egyszer használatos kompakt kitek, kondom vizelet elvezetők, a lábszár mellé rögzített intim gyújtők használata. Sajnos az OEP adatai azt mutatják, hogy az utóbbi években nem fejlődött az ehhez szükséges neuro-urológiai hálózat, és csökkent az elvégzett kompex cisztometria + húgyúti nyomás-áramlás vizsgálatok száma. Ezért 2015-ben az OORI-ban megkezdte munkáját OEP befogadással az első akadálymentes ilyen rendelő, ahol a súlyosabb, bénult beteget is könynyen fel lehet fektetni a vizsgáló asztalra.

A rehabilitáció területén végzett kutatások a közeljövőben tovább szélesednek, és ebben nagy lehetőséget jelentenek a korszerű elektronikai és informatikai lehetőségek: iris vezérelt számítógép használata, telemedicina (pl. távlogopédia), robot asszisztált fizioterápia, funkcionális elektromos stimuláció (FES - alsó végtagi koordinált izomingerléssel - például kerékpározás imitációja stb.).

A rehabilitáció hazai fejlődésében meghatározó lehet a továbbiakban a társadalmi attitűd változása. Ha tovább erősödik a radikalizmus, a kirekesztésre való hajlandóság, az nem kedvez az alapvetően szolidaritásra épülő fogyatékos ügynek. Ennek kiemelkedő eleme az akadálymentesség kialakításának folytatása úgy a köztereken, mint a civil szféra egyéb területein és az otthonokban. Ez utóbbinál felmerül az, hogy az életvitelt segítő, de jellemzően nem gyógyászati segédeszközök (speciális ágyak, betegemelők) hozzáféréséhez is lehetséges legyen költségvetési 
támogatást igénybe venni, például a szociális kassza új fejezetében, és akár a kölcsönzést priorizálva.

Az ismert okokból deformált hazai adómorál mellett, a bevallott jövedelmek után befizetett kevesebb járulék gyakran nem teremt fedezetet a munkaképességet is segítő speciális eszközök (pl. állító kerekesszék) biztosítására, ilyenkor látható, hogy a hazai biztosítási környezet nem motivált a minél nagyobb mértékű társadalmi reintegráció elérésére. Emiatt az akadályozott emberek a mindennapi élet során számos nehézséggel néznek szembe: nem tudnak lakásukba akadálymentes (pl. kerekesszékkel szemből megközelíthető) bútort venni, nem érik el a kerekesszékből közterületeken a funkcionális pontokat (parkoló automata), a gyermekek az akadálymentesség hiánya miatt nem tudnak integrált nevelésben részesülni.

Ebből is következik, hogy számos munkavégzési forma (külterület, építkezés, ipari múhely) számukra még alig érhető el, jellemző az átképzés után végezhető adminisztratív, informatikai munkakör lehetősége.

Ha a testi funkciók károsodásának korrekciója és a munkahelyi integráció elmaradása ilyen fokú, még problémásabbnak nevezhető a szabadidő eltöltésének szervezettsége. Hazánkban ma kifejezetten alacsony a kerekes székkel élőknek turisztikai programot ajánló szervezetek száma, az akadálymentesség hiánya miatt nehezen megközelíthetők számukra az erdei túraösvények, strandok, de sokszor még a színházak is.

Hasonlóan kialakulatlan a speciális családtervezési hálózat, nemigen állnak rendelkezésre például gerincvelősérültek számára speciális infertilizációs, andrológiai szakrendelések és osztályok.

A parasport jelentősége ugyanakkor lassan, de hazánkban is kezd az elfogadott kategóriába kerülni, az ilyen sportolók sikerei nagyban hozzájárulnak a társadalmi attitúd változásához, de akár sorstársaik mindennapos küzdelmeikben való megerősítéséhez is.

A következő időszakban számos jubileumot ünnepelhetünk majd. Az Országos Orvosi Rehabilitációs Intézet, mint országos intézet megalakulásának 40 éves ünnepsége 2015. decemberében lesz. Jövőre, 2016-ban kerül sor az ismét régi nevét választó Magyar Rehabilitációs Társaság (MRT) 50 éves megalakulásának megünneplésére nemzetközi kongresszus keretében. Jól jelzi a szakmák közötti együttmúködést, hogy az MRT egyik megalapítója dr. Egyed Béla egyben annak a Baleseti Rehabilitációs Osztálynak is alapítója volt, amely jövőre ünnepli fennállásának 55 jubileumát a majd 60 éves egykori Országos Traumatológiai Intézetben.

Csak azt kívánhatom, hogy e nemes alapokon továbbra is a betegek komplex ellátását szolgáló gyümölcsöző együttmúködés legyen szakmáink és intézeteink között! 


\section{AJÁNLOTT IRODALOM}

1. Bálint G., Bálint P.: A fizikoterápia eszköztárának felhasználása a gyógyításban: hö-, fény-, elektromos, mágneses, ultrahang- és lökéshullám-kezelés, valamint az orvosi masszázs alkalmazása a hazai klinikai gyakorlatban. Orvosi Hetilap, 2013. 154. (48): 1905-1911. https://doi.org/10.1556/OH.2013.29760

2. Bálint G., Ormos G.: Sürgősség és mozgásszervi rehabilitáció. Rehabilitáció. 2009. 19. (1): 14-17.

3. Boda A.: Az Országos Orvosi Rehabilitációs Intézet Szeptikus és Tbc-s Mozgásszervi Rehabilitációs Osztályának 30 éve. Rehabilitáció. 2005. 15. (4): 40-45.

4. Boros E.: Az Országos Orvosi Rehabilitációs Intézet Vegyes Profilú Mozgásszervi Rehabilitációs Osztályának bemutatása. Rehabilitáció. 2010. 20. (2): 114-118.

5. Bors K.: A csonttörést szenvedett osteoporosisos beteg rehabilitációja. Ca és Csont. 2009. 12. (1): 23-27.

6. Cserháti P., Laczkó T., Flóris I., Somogyi P.: A csípőtáji törések kezelésének és rehabilitációjának értékelése a SAHFE európai projekt révén. Rehabilitáció. 2010. 20. (2): 96-101.

7. Cserháti P.: Kétoldali femur diaphysistörés ismetelten hibásan operált esete mindkétoldali következményes fáradásos combnyaktöréssel. Magyar Traumatológia Orthopaedia és Helyreállitó Sebészet. 1991. 34. (1): 73-76.

8. Cserháti P., Laczkó T., Vendégh Zs., Bodzay T., Kazár Gy., Manninger J.: A combnyaktáji törés utáni rehabilitáció hazai problémái és a fejlesztés lehetőségei. Magyar Traumatológia Orthopaedia és Helyreállitó Sebészet. 1992. 35. (2): 149-154.

9. Dénes Z., Baleset következtében súlyos agykárosodást szenvedett betegek rehabilitációjának eredményei. Orvosi Hetilap. 2005.146. (47): 2403-2406.

10. Dénes Z., Lantos Á., Thomka M., Vass M.: Baleset következtében súlyos agykárosodást szenvedett idős betegek rehabilitációja. Rehabilitáció. 2010. 20. (1): 16-19.

11. Dénes Z., Urbanics I., Verseghi A.: A súlyos agysérült betegek kórházi rehabilitációs idejének hossza, problémái. Rehabilitáció. 2014. 24. (2-3): 58-64.

12. Egyed B.: Mozgásszervi sérültek rehabilitációja. Budapest, Medicina. 1983.

13. Fazekas G., Fehér M., Arz G., Stefanik Gy., Boros Zs., Tóth A.: Felső végtagi bénultak segédeszközeinek új generációja : robotok a mozgásszervi rehabilitációban. Rehabilitáció. 2002. 12. (3): 6-9.

14. Flóris I., Kricsfalusy M., Udvardy Cs., Somogyi P.: A csípőtáji combcsonttörést szenvedett betegek kezelése és rehabilitációja napjainkban : az ortopéd traumatológusok szerepe a betegek osteoporosisának kivizsgálásában és kezelésében. Lege Artis Medicinae KID. 2011. 1. (2): 41-45.

15. Gresz M., Borbás F., Csordás A., Dózsa Cs.: A hosszú távú ellátások kapacitás- és igénybevételi adatainak elemzése. IME. 2014.13. (2): 7-12.

16. Heikkinen $T$, Partanen J, Ristiniemi J, Jalovaara P. Evaluation of 238 consecutive patients with the extended data set of the Standardised Audit for Hip Fractures in Europe (SAHFE). Disabil Rehabil. 2005. 27. (18-19): 1107-1115. https://doi.org/10.1080/09638280500061220

17. Katona F., Siegler J. (szerk.): A rehabilitáció gyakorlata. Budapest, Medicina. 2004.

18. Katona F., Siegler J. (szerk.): Ovosi rehabilitáció. Budapest, Medicina. 1998.

19. Klauber A., Molnár F.: Gerincvelö sérültek rehabilitációja Magyarországon 1962-töl 1987-ig. Összefoglaló statisztikai áttekintés. Magyar Traumatológia Orthopaedia és Helyreállitó Sebészet. 1990. 33. (1): 51-53. p.

20. Kullmann L.: Mozgásszervi rehabilitáció. Orvosképzés. 1998. 73. (6): 365-368.

21. Major G.: A müvégtaggal való ellátás napjainkban. Magyar Orvos. 2010. 18. (10): 36.

22. Major G.: A rehabilitációs munka egyik akadályozója: a decubitus. Magyar Orvos. 2009. 17. (11): 36-39.

23. Manninger, J., Bosch, U., Cserháti, P., Fekete, K., Kazar, G. (Hrsg.): Osteosynthese der Schenkelhalsfraktur. Wien etc., Springer. 2005. https://doi.org/10.1007/b138815

24. Mészáros G., Szikriszt É.: Mitöl lehetne eredményesebb az időskorúak rehabilitációja? Rehabilitáció. 2010. 20. (2): 83-89.

25. Mészáros Sz., Horváth Cs., Ferencz V., Tabák Á., Boros E., Czeglédi K., Hegedüs B., Huszár S., Kinda I., Krunity X., Sárosi K., Taniszláv E., Bors K.: Különbözö törési kockázatbecslö módszerek összehasonlitása mozgásszervi rehabilitációs programban részt vevő betegeken. Rehabilitáció. 2013. 23. (1-2): 22-28.

26. Mogánné Tölgyesy Sz.: A foglalkoztató terápia szerepe a mozgásszervi rehabilitációban. Rehabilitáció. 1996. 6. (3): 48-53.

27. Molics B., Boncz I., Leidecker E., Horváth Z., Sebestyén A., Kránitz J., Komoly S., Dóczi T., Oláh A.: A neurológiai kórképek fizioterápiás ellátásának egészségbiztositási vonatkozásai a járóbetegszakellátásban. Ideggyógyászati Szemle. 2015. 68. (11-12): 399-408.

28. Országos Epidemiológiai Központ: Az aktiv fekvőbeteg-ellátó intézetek rehabilitációs és krónikus osztályain 2013. évben végzett, egészségügyi ellátással összefüggő fertőzések és antbiotikum-felhasználás pont-prevalencia vizsgálat (PPV) eredményei. Epinfo. 2014. 21. (23): 261-266.

29. Pettyán I., Béresné Lutter M.: A fejlödés útja a magas szintü rehabilitációs tevékenységhez. Rehabilitáció. 2013. 23. (3): 82-90.

30. Sallai J., R., Hunka A., Rtakó I., Nagy Zs., Czimbalmos Á., Héjj G., Bálint G.: A mozgásszervi rehabilitációs osztályon kezeltek demográfiai és jövedelmi adatai, életminőségük, segítségre szorulásuk mértéke. IME. 2010. 9. (9): 40-47.

31. Sebestyén A., Boncz I., Tantó Zs., Péley I., Nyárády J.: Fekvőbeteg-rehabilitáció a 60 év alatti medialis combnyaktöröttek ellátását követö két évben. Rehabilitáció. 17. (1): 10-16.

32. Vachter A.: Humánerőforrás-fejlesztés és teljesitménymérés lehetőségei mozgásszervi rehabilitációs osztályon. Nővér. 2003.16. (1): 3-9. 
33. Váry A., Mészáros G., Molnár F.: Baleseti mozgássérültek pszichoszociális rehabilitációja. Rehabilitáció. 1991. 1. (4): 1-3.

34. Vén I.,Vass I., Putz M.: Kórház kontra lakóközösség. Mely körülmények kedvezöbbek az idöskorú sérültek rehabilitációjához. Rehabilitáció. 2010. 20. (2): 70-77.

35. Yakub F., Khudzari AZ., Mori Y.: Recent trends for practical rehabilitation robotics, current challenges and the future. Int. J. Rehabil. Res. 2014. 37. (1): 9-21. https://doi.orq/10.1097/MRR.0000000000000035

\section{Dr. Cserháti Péter Ph.D.}

mb. tanszékvezető, Pécsi Tudományegyetem, Klinikai Központ,

Orvosi Rehabilitáció és Fizikális Medicina önálló Tanszék

Főigazgató, Országos Orvosi Rehabilitációs Intézet 